\title{
Rapid Diagnosis of Pseudomonas syringae pv. papulans, the Causal Agent of Blister Spot of Apple, by Polymerase Chain Reaction Using Specifically Designed hrpL Gene Primers
}

\author{
Mohamed Kerkoud, Charles Manceau, and Jean Pierre Paulin
}

INRA-UMR de Pathologie Végétale, Institut National de la Recherche Agronomique, B.P. 57, 42 rue G. Morel, 49071 Beaucouzé Cedex, France.

Accepted for publication 21 May 2002.

\begin{abstract}
Kerkoud, M., Manceau, C., and Paulin, J. P. 2002. Rapid diagnosis of Pseudomonas syringae pv. papulans, the causal agent of blister spot of apple, by polymerase chain reaction using specifically designed $h r p L$ gene primers. Phytopathology 92:1077-1083.

The identification and detection of Pseudomonas syringae pv. papulans, the causal agent of blister spot of apple, on apple leaves and fruit was achieved by polymerase chain reaction amplification of a specific DNA fragment of the $h r p L$ sequence. The consensus primers $\mathrm{hrpL}_{1}$ and $\mathrm{hrpL}_{2}$ were designed based on the alignment of pseudomonad $h r p L$ gene sequences available in nucleic acid data banks. This primer set produced a 631-bp amplicon from 37 of the 57 pseudomonads strains tested. These strains belonged to genomospecies 1 and 2, as described by Gardan et al. (8). The amplicon obtained from 30 of these strains was digested with

duced from strains belonging to genomospecies 1, resulting in A1 and A2 patterns, while strains belonging to genomospecies 2 were characterized by a B pattern. Patterns A1 and A2 differed at only two sites, a Bsp 143I site located at nucleotide 360 and a MseI site located at nucleotides 2224. Group A2 consisted solely of $P$. syringae pv. papulans strains. The hrpL gene in $P$. syringae pv. papulans strain CFBP3323 was sequenced. Two primer sets, Pap1/Pap2 and Pap1/Pap3, were designed and tested for specificity to $P$. syringae pv. papulans. These primers amplified expected fragments of 242 and $303 \mathrm{bp}$, respectively. Pap1/Pap2 amplified a fragment only with $P$. syringae pv. papulans DNA, while Pap1/Pap3 amplified all tested strains belonging to genomospecies 1 . A diagnostic procedure using the Pap1/Pap2 primer set was successful for the detection of $P$. syringae pv. papulans in diseased fruit and artificially inoculated leaves.
\end{abstract} eight restriction enzymes. Three different restriction patterns were pro-
Pseudomonas syringae pv. papulans is the causal agent of blister spot of apple. It is the most important disease of the apple cv. Mutsu in the eastern United States (4), Canada (7), and Italy (2). Recently, blister spot was reported in Germany (21) and France (12). Epiphytic population studies of $P$. syringae in French pome orchards revealed the occurrence of $P$. syringae pv. papulans where natural symptoms had never been observed (12).

$P$. syringae is subdivided into pathovars differentiated primarily on the basis of their host plants and the symptoms that they cause. Each pathovar typically has strong biochemical, immunological, and DNA relatedness to several other pathovars, including $P$. syringae pv. syringae, which can be isolated from many plants (including apple), even though they are not pathogenic on these plants. Classical methods for the detection and identification of $P$. syringae pv. papulans rely on the isolation of the bacterium on nutrient agar medium and performance of specific biochemical, serological, and pathogenicity tests $(3,8,12)$. These tests take time and are expensive. Therefore, molecular tools (18) for detecting and identifying this pathovar are a promising alternative.

The polymerase chain reaction (PCR) has been used widely in molecular biology for the past 15 years. It is a very powerful methodology which has great potential for use in the identification and detection of microorganisms because of its rapidity, sensitivity, and specificity. The specificity of PCR is determined mainly by the primers. Thus, sequence analyses of the genomes of pathogenic bacteria are critical for the design of specific primers. In this paper we describe the approach that we used to design primers

Corresponding author: C. Manceau; E-mail address: manceau@angers.inra.fr

Publication no. P-2002-0729-01R

(c) 2002 The American Phytopathological Society specific to $P$. syringae pv. papulans, using the $h r p L$ gene as a target. This gene encodes an alternative sigma factor that belongs to the sigma-70-type sigma factor family (17) and is required for the expression of the hrp gene cluster in P. syringae (16), which encodes a type III secretion system essential for pathogenicity and host range (11). The sensitivity of a PCR assay is limited by the specificity of the primers used, the recovery of the target sequences, and the efficiency of the enzymatic reaction. Taq DNA polymerase is sensitive to inhibition by factors present in biological samples. Therefore it is evident that sample preparation should ensure both the removal or blocking of inhibitory substances and a high yield of amplifiable DNA. The objective of this work was to describe primers specific to $P$. syringae pv. papulans and to develop a reliable assay for the extraction of DNA and amplification by PCR of specific $P$. syringae pv. papulans target sequences from infected apple fruit and leaves.

\section{MATERIALS AND METHODS}

Bacterial strains. Eighteen strains of $P$. syringae pv. papulans isolated from different geographical areas (United States, Canada, Italy, and France) and 49 reference and type strains of other $P$. syringae pathovars and related species were used. In addition to the pseudomonads, isolates of four different species from rosaceous trees were tested (Table 1). All strains were stored as lyophilized stocks or frozen at $-80^{\circ} \mathrm{C}$ in liquid King's medium B (KB) (13) with glycerol $(40 \%, \mathrm{wt} / \mathrm{vol})$ and were restreaked for colony uniformity on $\mathrm{KB}$ agar.

Sample preparation for direct PCR from cell cultures. Bacterial cells grown on $\mathrm{KB}$ agar for $24 \mathrm{~h}$ were resuspended in sterile distilled water. The cell suspensions (approximately $1 \times 10^{7}$ cells $\mathrm{ml}^{-1}$ ) were boiled for $10 \mathrm{~min}$ and used for the PCR assay. 
PCR conditions for amplification of $h r p L$ region of $P$. syringae. The nucleotide sequence of $P$. syringae pv. syringae Pss61 hrpL genes (27) (GenBank Accession No. U03854) was compared with that of $P$. syringae pv. morsprunorum PM7 hrpL genes (15) (GenBank Accession No. L3653). Primers were selected from conserved regions of these $h r p L$ genes. Primers hrpL 1 (5'-GCGAGTTGGTTCCAGACAG-3') and $\mathrm{hrpL}_{2}$ (5'-GGTTATCGCTATAGGGCTTGC-3') are located 44 bp upstream of the $h r p L$ gene and $21 \mathrm{bp}$ before the stop codon, respectively. Oligonucleotides were synthesized by Eurogentec, Seraing, Belgium. PCR reactions were carried out in a 100- $\mu$ l reaction volume. A volume of $10 \mu \mathrm{l}$ of boiled bacterial cells was added to $90 \mu \mathrm{l}$ of PCR reaction mixture, consisting of $10 \mathrm{mM}$ Tris- $\mathrm{HCl}(\mathrm{pH}$ 9); $50 \mathrm{mM} \mathrm{KCl} ; 1 \%$ Triton $\mathrm{X}-100 ; 3 \mathrm{mM} \mathrm{MgCl}{ }_{2}$; dATP, dCTP, dGTP, and dTTP $(0.25 \mathrm{mM}$ each) (Eurogentec SA); 20 pmol of each primer; and 2 units of Taq DNA polymerase (Eurotaq, Eurogentec) at $25^{\circ} \mathrm{C}$. PCR amplifications were performed in a PTC-100 thermocycler (MJ Research, Watertown, MA) as follows: an initial denaturation step at $92^{\circ} \mathrm{C}$ for $2 \mathrm{~min}$ and then 35 cycles of $92^{\circ} \mathrm{C}$ for $1 \mathrm{~min}, 52^{\circ} \mathrm{C}$ for $1 \mathrm{~min}$, $72^{\circ} \mathrm{C}$ for $1 \mathrm{~min}$; and a final extension at $72^{\circ} \mathrm{C}$ for $2 \mathrm{~min}$. Amplified DNA fragments were examined by horizontal electrophoresis in $2 \%$ agarose gels (1\% Seakem GTG plus $1 \%$ Nuseive GTG, FMC Bioproducts, Rockland, ME) in TBE buffer $(19,26)$ with $10-\mu l$ aliquots of PCR products. Gels were stained with ethidium bromide $\left(1 \mu \mathrm{g} \mathrm{ml}^{-1}\right)$ and photographed under UV light $(312 \mathrm{~nm})$.

DNA sequencing. The DNA fragment obtained after PCR of $P$. syringae pv. papulans strain CFBP3323 was isolated from the agarose gel and purified using a silica-based procedure (UltraClean 15 DNA purification kit, Mo Bio Laboratories, Solana Beach, CA) as described by the manufacturer. The DNA fragments were cloned in the pGEM-T easy plasmid (Promega France) according to the manufacturer's instructions. Recombinant plasmids were introduced into $E$. coli strain DH5 $\alpha$ by transformation (10). Cloned DNA fragments were sequenced by using a Taq DyeDeoxy terminator cycle sequencing kit (Applied Biosystems, Fester City, CA) and a model ABI377 automatic sequencer. The complete DNA sequence was determined by using T7 and SP6 primers on DNA fragments cloned in pGEM-T easy plasmid. Both strands of two clones were sequenced.

Restriction fragment analysis. The following enzymes were used: Bsp143I, Hae III, HhaI, MspI, TaqI (Eurogentec); MseI, Tsp509I (New England Biolabs, Ozyme, Montigny le Bretonneux, France); and Sau96I (GIBCO-BRL, Life Technologies, Eragny, France). PCR products $(95 \mu \mathrm{l})$ were ethanol-precipitated and resuspended in $100 \mu \mathrm{l}$ of sterile distilled water; $10 \mu \mathrm{l}$ was used for each digestion. Digestions were performed as described by the

TABLE 1. Bacterial strains used in this study and results of polymerase chain reaction (PCR) assays

\begin{tabular}{|c|c|c|c|c|c|c|}
\hline & \multirow{2}{*}{$\begin{array}{c}\text { Strain } \\
\text { number } \\
(\mathrm{CFBP})^{\mathrm{a}}\end{array}$} & \multirow[b]{2}{*}{ Host } & \multirow[b]{2}{*}{ Origin } & \multicolumn{3}{|c|}{ PCR results ${ }^{\mathrm{b}}$ with: } \\
\hline & & & & $\begin{array}{c}\text { hrpL } \\
\text { primers }\end{array}$ & $\begin{array}{l}\text { Pap1/Pap2 } \\
\text { primers }\end{array}$ & $\begin{array}{c}\text { Pap1/Pap3 } \\
\text { primers }\end{array}$ \\
\hline \multicolumn{7}{|c|}{ Pseudomonas syringae genomospecies $1^{\mathrm{c}}$} \\
\hline \multirow[t]{5}{*}{ P. syringae pv. syringae } & $1392^{\mathrm{T}}$ & Syringa vulgaris & U.K. & $+\mathrm{A} 1$ & - & + \\
\hline & 1391 & Pyrus communis & U.K. & $+\mathrm{A} 1$ & - & + \\
\hline & 3077 & Pyrus communis & France & $+\mathrm{A} 1$ & - & + \\
\hline & 602 & Malus sylvestris & France & $+\mathrm{A} 1$ & - & + \\
\hline & 2559 & Malus sylvestris & France & $+\mathrm{A} 1$ & - & + \\
\hline P. syringae pv. aptata & 1617 & Beta vulgaris & U.S. & $+\mathrm{A} 1$ & - & + \\
\hline P. syringae pv. lapsa & 1731 & Triticum aestivum & Unknown & NT & - & + \\
\hline \multirow{18}{*}{ P. syringae pv. papulans } & 1754 & Malus sylvestris & Canada & $+\mathrm{A} 2$ & + & + \\
\hline & 3324 & M. sylvestris cv. Mutsu & Canada & $+\mathrm{A} 2$ & + & + \\
\hline & 5040 & M. sylvestris cv. Mutsu & Canada & $+\mathrm{A} 2$ & + & + \\
\hline & 5041 & M. sylvestris cv. Mutsu & Canada & $+\mathrm{A} 2$ & + & + \\
\hline & 5731 & M. sylvestris cv. Mutsu & U.S. & $+\mathrm{A} 2$ & + & + \\
\hline & 3323 & M. sylvestris cv. Mutsu & U.S. & $+\mathrm{A} 2$ & + & + \\
\hline & 5043 & M. sylvestris cv. Mutsu & U.S. & $+\mathrm{A} 2$ & + & + \\
\hline & 5044 & M. sylvestris cv. Mutsu & U.S. & $+\mathrm{A} 2$ & + & + \\
\hline & 5045 & M. sylvestris cv. Mutsu & U.S. & $+\mathrm{A} 2$ & + & + \\
\hline & 5046 & M. sylvestris cv. Mutsu & U.S. & $+\mathrm{A} 2$ & + & + \\
\hline & 5047 & M. sylvestris cv. Mutsu & U.S. & $+\mathrm{A} 2$ & + & + \\
\hline & 5048 & M. sylvestris cv. Mutsu & U.S. & $+\mathrm{A} 2$ & + & + \\
\hline & 5049 & M. sylvestris cv. Mutsu & U.S. & $+\mathrm{A} 2$ & + & + \\
\hline & 5134 & M. sylvestris cv. Mutsu & Italy & $+\mathrm{A} 2$ & + & + \\
\hline & 5135 & M. sylvestris cv. Golden Delicious & Italy & $+\mathrm{A} 2$ & + & + \\
\hline & 5728 & M. sylvestris cv. Golden Delicious & Italy & $+\mathrm{A} 2$ & + & + \\
\hline & 5132 & M. sylvestris cv. Golden Delicious & France & $+\mathrm{A} 2$ & + & + \\
\hline & 5133 & M. sylvestris cv. Golden Delicious & France & $+\mathrm{A} 2$ & + & + \\
\hline P. syringae pv. pisi & 2105 & Pisum sativum & New Zealand & $+\mathrm{A} 1$ & - & + \\
\hline P. syringae pv. atrofaciens & 2213 & Triticum aestivum & New Zealand & $+\mathrm{A} 1$ & - & + \\
\hline P. syringae pv. aceris & 2339 & Acer sp. & U.S. & $+\mathrm{A} 1$ & - & + \\
\hline P. syringae pv. panici & 2345 & Panicum sp. & U.S. & $+\mathrm{A} 1$ & - & + \\
\hline P. syringae pv. dysoxyli & 2356 & Dysoxylum spectabile & New Zealand & $+\mathrm{A} 1$ & - & + \\
\hline P. syringae pv. japonica & 2896 & Hordeum vulgaris & Japan & $+\mathrm{A} 1$ & - & + \\
\hline \multicolumn{7}{|l|}{ P. syringae genomospecies 2} \\
\hline P. savastanoi & $1670^{\mathrm{T}}$ & Olea europea & Yugoslavia & $+\mathrm{B}$ & - & - \\
\hline P. ficuserectae & $3224^{\mathrm{T}}$ & Ficus erecta & Japan & NT & - & - \\
\hline P. meliae & $3225^{\mathrm{T}}$ & Melia azerdarach & Japan & $+\mathrm{B}$ & - & - \\
\hline P. amygdali & $3340^{\mathrm{T}}$ & Prunus amygdalus & Greece & NT & - & - \\
\hline P. syringae pv. phaseolicola & 1390 & Phaseolus vulgaris & Canada & $+\mathrm{B}$ & - & - \\
\hline \multirow[t]{2}{*}{ P. syringae pv. ulmi } & 1407 & Ulmus sp. & Yugoslavia & NT & - & - \\
\hline & & & & & \multicolumn{2}{|c|}{ (continued on next page) } \\
\hline
\end{tabular}

a CFBP, Collection Française de Bactéries Phytopathogènes. T, type strain.

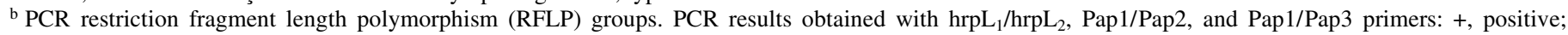
- , negative; NT, not tested.

c Genomospecies according Gardan et al. (8). 
supplier but with an excess of enzyme (5 units per reaction). Restricted DNA was analyzed by horizontal electrophoresis in 3\% agarose gels (1\% SeaKem GTG plus 2\% Nuseive GTG, FMC Bioproducts) as described above. The technique permitted the clear visualization and estimation of the length of DNA fragments longer than $70 \mathrm{bp}$ and permitted the visualization of poorly resolved fragments between 40 and 70 bp long.

Data analysis. The restriction maps were determined from restriction fragment length polymorphisms (RFLPs) by comparison with those inferred from the $h r p L$ sequence of $P$. syringae $\mathrm{pv}$. papulans strain CFBP3323. In this study, restriction and nucleotide sites were numbered starting from the first nucleotide identified in the sequence of strain CFBP3323 (Fig. 1).

PCR detection of $P$. syringae pv. papulans in infected pome tissues. Artificially inoculated apple fruit was used for direct detection of $P$. syringae pv. papulans in plant tissues. Detached immature fruit of the apple cv. Golden Delicious was inoculated in the laboratory by vacuum infiltration (12) with a suspension of bacteria $\left(10^{7} \mathrm{CFU} \mathrm{ml^{-1 }}\right)$ in sterile distilled water. Controls were inoculated with sterile distilled water. Inoculated fruit was enclosed in clear plastic bags and incubated in a growth chamber $\left(25^{\circ} \mathrm{C}, 8 \mathrm{~h}\right.$ darkness a day) for 4 weeks. From each infected fruit, transverse sections with blister spots were individually transferred to $1.5-\mathrm{ml}$ sterile Eppendorf tubes and crushed in $200 \mu \mathrm{l}$ of sterile distilled water. The bacterial cells were allowed to diffuse from plant tissues for $15 \mathrm{~min}$. Undiluted and 10-fold-diluted preparations were used directly for PCR detection. DNA was also extracted by the following procedure: $20 \mu \mathrm{l}$ of soaking liquid was added to $80 \mu \mathrm{l}$ of lysis buffer, containing $0.2 \mathrm{M}$ Tris $\mathrm{HCl}(\mathrm{pH} 7.5$ ), $0.25 \mathrm{M} \mathrm{NaCl}, 0.25 \mathrm{M}$ EDTA, sodium dodecyl sulfate $(0.5 \%$, $\mathrm{wt} / \mathrm{vol})$, and polyvinylpyrrolidone 360 (2\%, wt/vol), after Edwards et al. (8), and left at room temperature for $10 \mathrm{~min}$; DNA was extracted from the lysis solution by a silica-based procedure (Ultraclean 15 DNA purification kit, Mo Bio Laboratories), as described by the manufacturer. A Genereleaser treatment was applied to DNA samples before PCR, as described by the manufacturer (Bioventures, Murfreesboro, Tennessee).

PCR detection of $P$. syringae pv. papulans in mixed leaf extracts. Leaves of the apple cv. Golden Delicious $(3 \mathrm{~g})$ were crushed in $18 \mathrm{ml}$ of extraction buffer $\left(8.5 \mathrm{mM} \mathrm{NH}_{4} \mathrm{H}_{2} \mathrm{PO}_{4}, 13.5 \mathrm{mM}\right.$ $\mathrm{KCl}$, and $8.3 \mathrm{mM} \mathrm{MgSO} 4 \cdot 7 \mathrm{H}_{2} \mathrm{O}, \mathrm{pH} 7.2$ ). Tenfold serial dilutions of a suspension of $P$. syringae pv. papulans (approximately $6 \times$ $10^{6} \mathrm{CFU} \mathrm{m}{ }^{-1}$ ) were made in leaf extract. Samples $(900 \mu \mathrm{l})$ of the bacterial suspensions were filtered through a paper disk (ref. 321861, Schleicher and Schuell, Dassel, Germany), and the bacteria were collected by centrifugation at $13,000 \times g$ for $10 \mathrm{~min}$. The pellet was resuspended in $100 \mu \mathrm{l}$ of Edwards's buffer and treated like infected pome tissue extracts.

PCR conditions for specific identification and detection of P. syringae pv. papulans. The designed primers were tested on a

\begin{tabular}{|c|c|c|c|c|c|c|}
\hline & \multirow{2}{*}{$\begin{array}{c}\text { Strain } \\
\text { number } \\
(\mathrm{CFBP})^{\mathrm{a}}\end{array}$} & \multirow[b]{2}{*}{ Host } & \multirow[b]{2}{*}{ Origin } & \multicolumn{3}{|c|}{ PCR results ${ }^{\mathrm{b}}$ with: } \\
\hline & & & & $\begin{array}{c}\text { hrpL } \\
\text { primers }\end{array}$ & $\begin{array}{c}\text { Pap1/Pap2 } \\
\text { primers }\end{array}$ & $\begin{array}{c}\text { Pap1/Pap3 } \\
\text { primers }\end{array}$ \\
\hline P. syringae pv. mori & 1642 & Morus alba & Hungary & $+\mathrm{B}$ & - & - \\
\hline P. syringae pv. sesami & 1671 & Sesamum indicum & Yugoslavia & NT & - & - \\
\hline P. syringae pv. tabaci & 2106 & Nicotiana tabacum & Hungary & $+\mathrm{B}$ & - & - \\
\hline P. syringae pv. morsprunorum & 1647 & Prunus avium & Italy & $+\mathrm{B}$ & - & - \\
\hline P. syringae pv. glycinea & $2214^{\mathrm{T}}$ & Glycine $\max$ & New Zealand & $+\mathrm{B}$ & - & - \\
\hline P. syringae pv. ciccaronei & 2342 & Ceratonia siliqua & Italy & NT & - & - \\
\hline \multicolumn{7}{|l|}{ P. syringae genomospecies 3} \\
\hline P. syringae pv. tomato & $2212^{\mathrm{T}}$ & Lycopersicon esculentum & U.K. & - & - & - \\
\hline P. syringae pv. persicae & $1573^{\mathrm{T}}$ & Prunus persica & France & - & - & - \\
\hline P. syringae pv. antirrhini & $1620^{\mathrm{T}}$ & Antirrhinum sp. & U.K. & - & - & - \\
\hline P. syringae pv. maculicola & $1657^{\mathrm{T}}$ & Brassica oleracea & New Zealand & - & - & - \\
\hline P. syringae pv. viburni & 1702 & Viburnum sp. & U.S. & - & - & - \\
\hline P. syringae pv. berberidis & 1727 & Berberis sp. & New Zealand & - & - & - \\
\hline P. syringae pv. apii & 2103 & Apium graveolens & U.S. & - & - & - \\
\hline P. syringae pv. delphinii & 2215 & Delphinium sp. & New Zealand & - & - & - \\
\hline P. syringae pv. passiflorae & 2346 & Passiflora edulis & New Zealand & - & - & - \\
\hline P. syringae pv. lachrymans & 2440 & Cucumis sativum & U.S. & - & - & - \\
\hline P. syringae pv. philadelphi & 2898 & Philadelphus coronarius & U.K. & - & - & - \\
\hline \multicolumn{7}{|l|}{$P$ syringae genomospecies 4} \\
\hline P. syringae pv. porri & 1908 & Allium porrum & France & - & - & - \\
\hline P. syringae pv. garcae & 1634 & Coffea arabica & Brazil & - & - & - \\
\hline P. syringae pv. striafaciens & 1674 & Avena sativa & Unknown & - & - & - \\
\hline P. syringae pv. coronafaciens & $2216^{\mathrm{T}}$ & Avena sativa & U.K. & - & - & - \\
\hline P. syringae pv. atropurpurea & $2340^{\mathrm{T}}$ & Lolium multiflorum & Japan & - & - & - \\
\hline P. syringae pv. oryzae & 3228 & Oryza sativa & Japan & NT & - & - \\
\hline \multicolumn{7}{|l|}{ P. syringae genomospecies 5} \\
\hline P. syringae pv. tremae & 3229 & Trema orientalis & Japan & NT & - & - \\
\hline \multicolumn{7}{|l|}{ P. syringae genomospecies 6} \\
\hline$P$. viridiflava & $2107^{\mathrm{T}}$ & Phaseolus sp. & Switzerland & - & - & - \\
\hline P. syringae pv. primulae & 1660 & Primula sp. & U.S. & NT & - & - \\
\hline \multicolumn{7}{|l|}{ P. syringae genomospecies 7} \\
\hline P. syringae pv. tagetis & $1694^{\mathrm{T}}$ & Tagetes erecta & Zimbabwe & - & - & - \\
\hline P. syringae pv. helianthi & 2067 & Helianthus annuus & Mexico & NT & - & - \\
\hline \multicolumn{7}{|l|}{ P. syringae genomospecies 8} \\
\hline$P$. syringae pv. theae & 2353 & Thea sinensis & Japan & - & - & - \\
\hline \multicolumn{7}{|l|}{ P. syringae genomospecies 9} \\
\hline P. syringae pv. cannabina & 2341 & Cannabis sativa & Hungary & - & - & - \\
\hline \multicolumn{7}{|l|}{ Other species } \\
\hline Erwinia amylovora & 1430 & Pyrus communis & France & - & - & - \\
\hline Erwinia herbicola & 1189 & Malus sylvestris & U.S. & - & - & - \\
\hline Pantoea agglomerans & 3615 & Wisteria floribunda & Japan & - & - & - \\
\hline Xanthomonas arboricola pv. pruni & 3566 & Prunus armeniaca & France & - & - & - \\
\hline
\end{tabular}


collection of $P$. syringae pv. papulans strains, related pseudomonads, and nonpseudomonad bacteria associated with rosaceous trees (Table 1). PCR components were $0.3 \mu \mathrm{l}$ of Taq DNA polymerase (Appligène, 5 units/ $\mu \mathrm{l}), 5 \mu \mathrm{l}$ of $10 \times$ buffer, and $3.5 \mu \mathrm{l}$ of dNTP (10 $\mu \mathrm{M}$ each); $5 \mu \mathrm{l}$ of $\mathrm{MgCl}_{2}(25 \mathrm{mM})$; and $1 \mu \mathrm{l}$ of primer Pap1/Pap2 or Pap1/Pap3 $(20 \mu \mathrm{M})$ in a final volume of $50 \mu \mathrm{l}$. Amplification was carried out as follows: one step at $92^{\circ} \mathrm{C}$ for $2 \mathrm{~min}$, followed by 35 cycles at $92^{\circ} \mathrm{C}$ for $1 \mathrm{~min}, 64^{\circ} \mathrm{C}$ for $30 \mathrm{~s}$, and $72^{\circ} \mathrm{C}$ for $1 \mathrm{~min}$, and then one step at $72^{\circ} \mathrm{C}$ for $1 \mathrm{~min}$. Amplified products were detected by agarose gel electrophoresis, as described above.

\begin{tabular}{|c|c|c|c|c|}
\hline & & $T \underline{S p}$ & 09 I & \\
\hline & & & MseI & \\
\hline 1 & ATAGGGCTTG & САCTCCATCA & $\begin{array}{c}\text { ATTAAGGCAA } \\
\text { Bsp143I }\end{array}$ & GTCCAGAGGC \\
\hline 41 & $\begin{array}{l}\text { AAGTCCTGCT } \\
\text { Pap1 }\end{array}$ & CCCGAATCTT & $\begin{array}{l}\text { GT } \overline{\text { GATCCTTG }} \\
\text { MspI }\end{array}$ & $\begin{array}{l}\text { ATGCAACCGA } \\
\text { MspI Tsp509I }\end{array}$ \\
\hline 81 & $\begin{array}{c}\text { ACCACGCCAA } \\
\text { HaeIII Bsp1 }\end{array}$ & $\begin{array}{l}\text { CCATCGTCAT } \\
\text { 43I Saug6 }\end{array}$ & CCGCCGGTAT & CCGGCAATTG \\
\hline 21 & ACGGC $\overline{C G A T C}$ & AGGTCCAGAT & GCTCAGAGCG & TTCATCCAGA \\
\hline 161 & AGCGGGTGAA & $\begin{array}{l}\text { GAACGCTGAT } \\
\text { TagI }\end{array}$ & GATGTGGATG & ACATCCTGCA \\
\hline 01 & ATGCGTGTTT & CTCGAGGCGT & TACGCAATGA & GCACAAGTTT \\
\hline 241 & $\begin{array}{l}\text { CAGCACGCCA } \\
\text { HhaI }\end{array}$ & $\begin{array}{l}\text { GCAAACCGCA } \\
\text { Bsp143I }\end{array}$ & AACCTGGTTG & $\begin{array}{r}\text { TGTGGCATTG } \\
\text { Pap2 }\end{array}$ \\
\hline 281 & CGCTGAATCT & 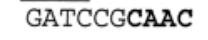 & CACTTTCGCA & AAATGTATCG \\
\hline 21 & $\begin{array}{l}\text { CCAGCCCTAT } \\
\text { Saug6 }\end{array}$ & $\begin{array}{l}\text { CAGGAAAGCT } \\
\text { TaqI Pap3 }\end{array}$ & GGGAAGACGA & GGTCCATACG \\
\hline 361 & $\begin{array}{l}\overline{\text { GACCTTGGAT }} \\
\text { HaeIII }\end{array}$ & CGAACGGCGA & $\begin{array}{r}\text { TATCACCCAT } \\
\text { HaeI }\end{array}$ & $\begin{array}{l}\text { CAGGTAGACG } \\
\text { II TaqI }\end{array}$ \\
\hline 01 & 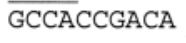 & GCTGGCACGC & GTCATAGAGG & CCATCGACTG \\
\hline 4. & CCTGCCGACG & $\begin{array}{c}\text { AATATGCAGA } \\
\text { Tsp509 I }\end{array}$ & AGGTTCTGGA & AGTTTCTCTG \\
\hline 481 & $\begin{array}{r}\text { GAAATGGATG } \\
\text { Bsp }\end{array}$ & $\begin{array}{l}\text { GCAATTATCA } \\
143 \mathrm{I}\end{array}$ & GGAAACCGCC & $\begin{array}{c}\text { AACATGCTCG } \\
\text { MspI }\end{array}$ \\
\hline 52 & GTGTTCCGAT & CGGCACTGTC & CGCTCCCGAC & TGTCCCGGGC \\
\hline 6 & ACGGGTGCAG & CTCAAGCAAC & AGATAGACCC & GTTCCCT \\
\hline
\end{tabular}

Fig. 1. Nucleotide sequence of an internal fragment of the $h r p L$ gene of Pseudomonas syringae pv. papulans strain CFBP3323. Sequence of primer Pap1 and complementary sequences of primers Pap2 and Pap3, designed to detect $P$. syringae pv. papulans, are in bold letters. Also shown are the restriction sites of Tsp509I, MseI, Bsp143I, MspI, HaeIII, Sau96, TaqI, and HhaI.

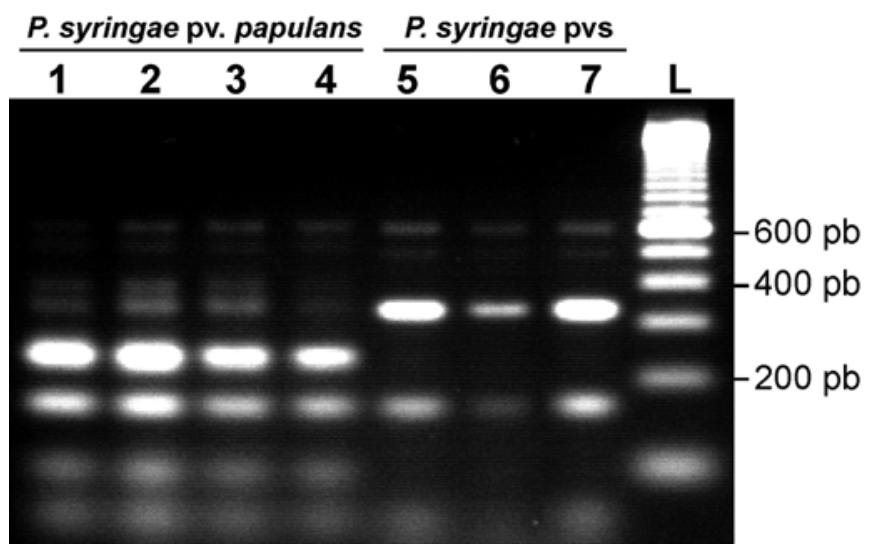

Fig. 2. Gel electrophoresis of an hrpL DNA fragment of Pseudomonas syringae digested with Bsp143I and amplified by polymerase chain reaction. Lanes 1 to 4: P. syringae pv. papulans strains CFBP3323, CFBP1754, CFBP5132, and CFBP3324. Lane 5: P. syringae pv. syringae strain CFBP1392 ${ }^{\mathrm{T}}$. Lane 6: P. syringae pv. aptata strain CFBP1617. Lane 7: P. syringae pv. lapsa strain CFBP1731. Lane L: DNA size markers (100-bp ladder, Life Technologies).

\section{RESULTS}

Nucleotide sequence of a segment of the $h r p L$ gene of $P$. $s y$ ringae pv. papulans strain CFBP3323. The 597-bp segment encoding part of the hrpL gene of $P$. syringae pv. papulans strain CFBP3323 was sequenced in both directions. Four restriction sites for Bsp143I, three restriction sites apiece for Hae III, TaqI, and Tsp509I, two restriction sites apiece for MspI and Sau96, and one restriction site apiece for HhaI and MseI were located in the sequence (Fig. 1). Their locations were verified by analysis of the electrophoretic patterns of digested amplified DNA fragments. hrpL sequences of $P$. syringae pv. syringae strain Pss61 (27) (GenBank Accession No. U03854) and P. syringae pv. phaseolicola strain 1302A (20) (GenBank Accession No. U16817) were used to precisely locate restriction sites which were not present in strain CFBP3323.

Restriction enzyme analysis of the amplified $h r p L$ gene fragments of $\boldsymbol{P}$. syringae. Stringent PCR conditions with primers $\mathrm{hrpL}_{1}$ and $\mathrm{hrpL}_{2}$ allowed the amplification of a single DNA fragment of the expected size $(631 \mathrm{bp})$ for only 37 of the 57 pseudomonad strains tested (Table 1). All tested strains that produced a DNA amplicon belonged to either genomospecies 1 or genomospecies 2, as defined by Gardan et al. (9). Digestion of the PCR products with eight restriction enzymes (Bsp143I, Hae III, Hha I, Mse I, Msp I, Sau96, TaqI, and Tsp509I) revealed polymorphisms in restriction patterns (as an example, results of digestion with Bsp143I are shown in Figure 2). Analysis of the diversity within this DNA fragment was performed using 30 restriction sites. Three different patterns were identified. Patterns A1 and A2 dif-

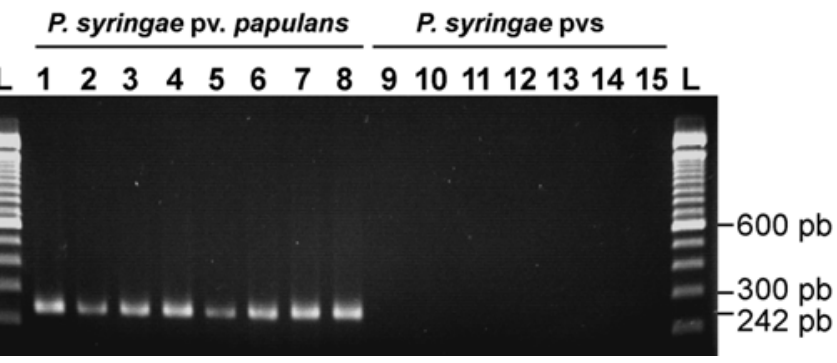

Fig. 3. Amplification of Pseudomonas syringae strains by polymerase chain reaction with primer set Pap1/Pap2. Lanes 1-8: P. syringae pv. papulans strains CFBP1754, CFBP3324, CFBP3323, CFBP5043, CFBP5134, CFBP5135, CFBP5132, and CFBP5133. Lane 9: negative control. Lane 10: P. syringae pv. syringae strain CFBP1392. Lane 11: P. savastanoi strain CFBP1670. Lane 12: P. syringae pv. tomato strain CFBP2212. Lane 13: $P$. syringae pv. garcae strain CFBP1634. Lane 14: P. viridiflava strain CFBP2107. Lane 15: P. syringae pv. tagetis strain CFBP1694. Lane L: DNA size markers (100-bp ladder, Life Technologies).

TABLE 2. Detection level of Pseudomonas syringae pv. papulans with PCR and plating assays

\begin{tabular}{lccccc}
\hline \multirow{2}{*}{$\begin{array}{l}\text { Dilution of bac- } \\
\text { terial suspension }\end{array}$} & \multicolumn{2}{c}{ PCR } & & \multicolumn{2}{c}{ Plating $^{\mathrm{b}}$} \\
\cline { 2 - 3 } \cline { 5 - 6 } & Water & Leaf extract & & Water & Leaf extract \\
\hline 0 & + & + & & + & $-^{\mathrm{c}}$ \\
$10^{-1}$ & + & + & & + & - \\
$10^{-2}$ & + & + & & + & - \\
$10^{-3}$ & + & + & & + & - \\
$10^{-4}$ & + & + & & $30^{\mathrm{d}}$ & - \\
$10^{-5}$ & - & - & & - \\
$10^{-6}$ & - & - & & - & - \\
\hline
\end{tabular}

a The initial concentration of the bacterial suspension was $6 \times 10^{6} \mathrm{CFU} \mathrm{ml}^{-1}$.

b Plating assays were performed on King's medium B.

c Colonies of $P$. syringae pv. papulans were undetectable among colonies of epiphytic bacteria, which numbered $1 \times 10^{6} \mathrm{CFU} \mathrm{ml}^{-1}$ in the leaf extract suspension.

d Average number of colonies detected on King's medium B (in $50 \mu \mathrm{l}$ ), corresponding to $6 \times 10^{2} \mathrm{CFU} \mathrm{ml}^{-1}$. 
fered at only two sites (Bsp143I at nucleotide 360 was present in A1 but absent in A2, and Mse I at nucleotides 22-25 was absent in A1 but present in A2). Pattern A2 was formed only by strains of $P$. syringae pv. papulans. Patterns $\mathrm{A} 1$ and $\mathrm{A} 2$ differed from pattern $\mathrm{B}$ at 22 and 21 of 30 sites, respectively. Patterns A1 and A2 were observed for all tested pathovars belonging to genomospecies 1 of $P$. syringae (including pathovars syringae, aptata, lapsa, pisi, atrofaciens, and papulans), whereas pattern B was observed for the seven tested members of genomospecies 2 ( $P$. savastanoi, $P$. meliae, and $P$. syringae pvs. phaseolicola, mori, tabaci, morsprunorum, and glycinea). These results suggested that it is possible to identify nucleotide sequences specific to $P$. syringae pv. papulans in the $h r p L$ gene.

Design of oligonucleotides specific to $P$. syringae pv. papulans. The DNA sequence of the $h r p L$ gene fragment of $P$. syringae pv. papulans strain CFBP3323 was used to perform a BLAST search of nucleotide data banks. The most similar sequence found was the $h r p L$ gene of $P$. syringae pv. pisi (GenBank Accession No. U95530). Three primers-Pap1 (5'-AACCACGCCAACCATCGTCA-3'), Pap2 (5'-GCGATACATTTTGCGAAAGTGGTTG-3'), and Pap3 (5'-GCCGTTCGACACCAGTCC-3') - were selected from regions where the number of mismatches was highest (Fig. 1). Pap3 was from the region where the restriction site Bsp143 $\mathrm{I}_{(360)}$ was located in the hrpL sequence of $P$. syringae pv. pisi. The primer sets Pap1/Pap2 and Pap1/Pap3 amplified fragments of the expected sizes, 242 and $303 \mathrm{bp}$, respectively, from $P$. syringae pv. papulans strains.

Primer specificity. The designed primers were tested on a collection of pseudomonads and bacteria common to rosaceous trees (Table 1). PCR was performed under high-stringency conditions (annealing at $64^{\circ} \mathrm{C}$ for $30 \mathrm{~s}$ ), which were compatible with the temperature melting of the primers and the high $\mathrm{G}+\mathrm{C}$ content of hrp clusters. The primer set Pap1/Pap2 was specific for $P$. syringae pv. papulans; only $P$. syringae pv. papulans strains amplified the 242-bp fragment (Fig. 3 and Table 1). However, the primer set Pap1/Pap3, which initiated amplification of a 303-bp DNA fragment from $P$. syringae pv. papulans strains, produced a fragment of the same size from all the other $P$. syringae genomospecies 1 pathovars that were tested (Table 1). Five repetitions of the experiments confirmed the reproducibility of these results.

Sensitivity of PCR detection using apple leaf tissue. Amplification products were detected using a $1 \times 10^{-4}$ dilution of bacterial suspension in sterile distilled water or crushed leaf liquid (Table 2). The level of detection corresponded to $600 \mathrm{CFU} \mathrm{ml}^{-1}$. The same detection level was obtained in leaf extracts, indicating that the DNA extraction procedure removed PCR inhibitors contained in the leaf extracts (Fig. 4 and Table 2). P. syringae pv. papulans was not detected by plating bacterial suspensions made in leaf extracts on KB because epiphytic bacteria outgrew the pathogen.

PCR detection in blister spots on fruit. No amplification product was obtained when PCR was performed directly on crude

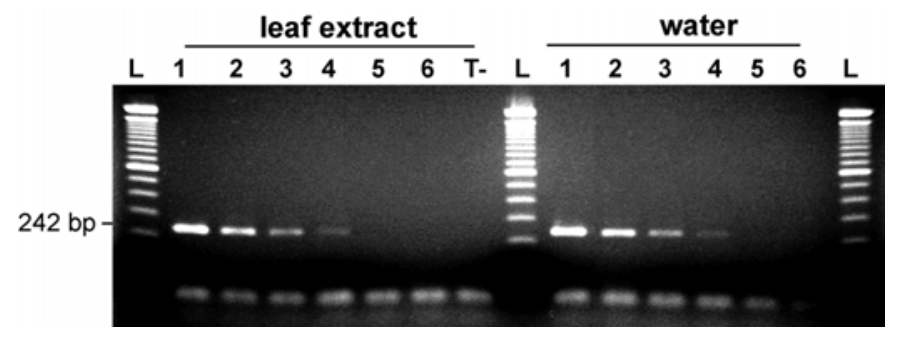

Fig. 4. Sensitivity of a polymerase chain reaction assay for detection of Pseudomonas syringae pv. papulans in apple leaf homogenate using primer Pap1/Pap2. Bacteria were added to healthy apple leaf extract and diluted in water to $1 \times 10^{-6}$. Lanes 1 to 6 : dilutions of $P$. syringae cells ranging from 6

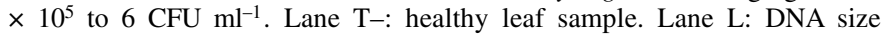
markers (100-bp ladder, Life Technologies). extracts of blister spots. However, a characteristic DNA fragment was observed when the extract was diluted 10-fold in sterile distilled water or when the DNA in the extract was purified as described in the Methods section (Fig. 5). DNA amplicons were digested with TaqI, and restriction products were separated by electrophoresis in agarose gel. Two fragments (108 and $134 \mathrm{bp}$ ) were observed in all cases (data not shown), which indicates that the amplicons correspond to the targeted DNA template of the $h r p L$ gene.

\section{DISCUSSION}

The pathogenicity-related gene $h r p L$ displayed a nucleotide sequence diversity similar to that observed in genes encoding housekeeping functions, such as $\operatorname{gyr} B$ and $r p o D$ (25), suggesting that the $h r p L$ gene is a good candidate for analysis of the evolutionary course of $P$. syringae sensu lato. Our results agree with those reported by Sawada et al. (25). Primers $h r p \mathrm{~L}_{1}$ and $h r p \mathrm{~L}_{2}$, used to amplify the $h r p L$ gene, allowed the amplification of a DNA fragment of $P$. syringae pathovars belonging to Sawada's $P$. syringae groups 2 and 3 only, but not those of group 1, based on gyrB, $r p o D, h r p L$, and hrpS DNA sequences (25). The RFLP data on the hrpL gene shows a correlation between the observed RFLP groups $\mathrm{A}$ and $\mathrm{B}$ and genomospecies 1 and 2, described by Gardan et al. (9). These observations confirm that the evolution of the $h r p L$ gene parallels speciation within the fluorescent oxidase-negative Pseudomonas group.

The tested strains of genomospecies 1 , which contains numerous pathovars, including the heterogeneous $P$ syringae $\mathrm{pv}$. syringae, appeared to be quite uniform in the RFLP pattern of the $h r p L$ gene. All pathovars displayed the same pattern except for $P$. syringae pv. papulans strains. However, $P$. syringae pv. papulans is not very different from the other pathovars of genomospecies 1 , as it differed in only two restriction sites out of 30 , which is very low in comparison with the 20 polymorphic sites noted between the groups A1-A2 and B. Additional polymorphic markers that would identify other pathovars or groups of pathovars probably exist in the hrpL nucleotide sequence, but RFLP analysis performed on 30 sites, which represent 120 nucleotides, did not reveal this polymorphism. DNA polymorphism analysis of the whole hrpL sequence of several pathovars of $P$. syringae, performed by Cournoyer et al. (6), indicated a division between $P$. syringae pv. syringae strain Pss61 and $P$. syringae pv. pisi strains. Furthermore, two lineages were described within $P$. syringae pv. pisi, based on $h r p L$ sequence data analysis, indicating that intrapathovar polymorphism can be observed at this locus. However, a BLAST search in nucleotide data banks showed that there were few differences between pathovars; the sequence of $P$. syringae pv. papulans strain CFBP3323 differed from that of $P$. syringae pv. pisi by only 14 or 15 nucleotides out of 584 (97\% identity).

Furthermore, our data indicate that $P$. syringae pv. papulans forms a uniform group, as all tested strains displayed exactly the

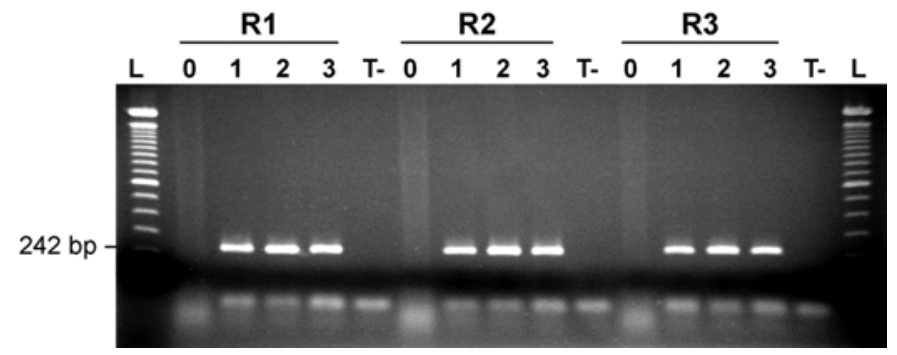

Fig. 5. Three representative results (R1, R2, and R3) of a polymerase chain reaction assay for direct detection of Pseudomonas syringae pv. papulans from blister spot lesions on apple fruit. Lane 0: undiluted crude sample. Lane 1: 10-fold diluted crude sample. Lanes 2 and 3: DNA purified from the crude and diluted samples, respectively. Lane T-: healthy fruit samples. Lane L: DNA size markers (100-bp ladder, Life Technologies). 
same RFLP pattern. This result led us to design oligonucleotides specific for the $h r p L$ gene as a diagnostic tool for P. syringae pv. papulans. The hrp region has already been used to design primers specific to plant-pathogenic bacteria, especially Xanthomonas (14). Three primers (Pap1, Pap2, and Pap3) were designed for $P$. syringae pv. papulans. Pap1 was designed as a forward primer and tested with Pap2 and Pap3 as reverse primers. Although Pap3 was designed with the discriminating $B \operatorname{sp} 143 \mathrm{I}_{(360)}$ site located at the 3 ' end, the primer set Pap1/Pap3 amplified all tested strains belonging to genomospecies 1 (Table 1). However, the primer set Pap1/Pap2 specifically amplified all strains of $P$. syringae pv. papulans. Pap1/Pap2 was designed after sequence alignment analysis. The Pap1/Pap2 primer set is a good tool for the identification of $P$. syringae pv. papulans, as it detected all strains of this pathovar, whatever the phenotypic polymorphism detected in these strains by biochemical and serological tests (12).

Hence, we developed two primer sets that allowed us to identify either $P$. syringae pv. papulans (Pap1/Pap2) or all $P$. syringae pathovars belonging to genomospecies 1 (Pap1/Pap3). Genomospecies 1 contains $P$. syringae pv. syringae, which groups pathogenic and nonpathogenic strains common on numerous plants, including apple. These two sets of primers represent good tools for monitoring the occurrence of these two $P$. syringae pathovars associated with apple. The specific Pap1/Pap2 primer set could be used for further epidemiological studies.

In Europe, apple blister canker has been observed in Italy and, recently, in Germany (21). Apple blister damage has been reported mainly on apple cv. Mutsu in North America and in Italy. However, other cultivars, such as Fuji, Golden Delicious, and Gala, are susceptible when young leaves or fruit is inoculated with $P$. syringae pv. papulans (12). In Germany, severe damage to cv. Delbarestivale was reported in several orchards in the Stuttgart area (21). The identity of the pathogen as strains of $P$. syringae pv. papulans was confirmed by PCR using the Pap1/Pap2 primer set (data not shown). The host range of $P$. syringae pv. papulans appears to be larger than the single cv. Mutsu, even under field conditions.

Enrichment procedures (26) have been developed to purify bacterial cells prior to PCR. In this study, pre-enrichment steps were not examined because one of our objectives was rapid detection, and pre-enrichment can be time consuming and labor-intensive. The PCR limit of detection of $P$. syringae pv. papulans was

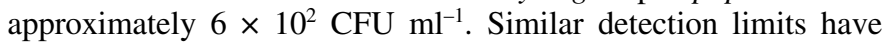
been described for the identification of $P$. syringae pv. pisi (1), $P$. corrugata (5), and Xanthomonas fragariae $(22,23)$.

In conclusion, a reliable and sensitive PCR assay has been developed for the detection of $P$. syringae pv. papulans on diseased fruit and leaves. It is a potentially useful tool for epidemiological studies of blister spot of apple.

\section{ACKNOWLEDGMENTS}

We thank E. Moltmann for providing German isolates of P. syringae pv. papulans.

\section{LITERATURE CITED}

1. Arnold, D. L., Athely-Pollard, A., Gibbon, M. J., Taylor, J. D., and Vivian, A. 1996. Specific oligonucleotide primers for the identification of Pseudomonas syringae pv. pisi yield one of two possible fragments by PCR amplification: Evidence for phylogenetic divergence. Physiol. Mol. Plant Pathol. 49:233-245.

2. Bazzi, C., and Calzolari, A. 1983. Bacterial blister spot of "Mutsu" apples in Italy. Phytopathol. Mediterr. 32:19-21.

3. Braun-Kiewnick, A., and Sands, D. C. 2001. Pseudomonas. Pages 84120 in: Laboratory Guide for Identification of Plant Pathogenic Bacteria. 3rd ed. N. W. Schaad, J. B. Jones, and W. Chun, eds. The American Phytopathological Society, St. Paul, MN.

4. Burr, T. J., and Hurwitz, B. 1979. The etiology of blister spot of "Mutsu" apple in New-York State. Plant Dis. Rep. 63:157-160.
5. Catara, V., Arnold, D., Cirvilleri, G., and Vivian, A. 2000. Specific oligonucleotide primers for the rapid identification and detection of the agent of tomato pith necrosis, Pseudomonas corrugata, by PCR amplification: Evidence for two distinct genomic groups. Eur. J. Plant Pathol. 106: 753-762.

6. Cournoyer, B., Arnold, D., Jackson, R., and Vivian, A. 1996. Phylogenetic evidence for a diversification of Pseudomonas syringae pv. pisi race 4 strains into two distinct lineages. Phytopathology 86:10511056.

7. Dhanvantari, B. N. 1977. A taxonomic study of Pseudomonas papulans Rose 1917. N.Z. J. Agric. Res. 20:557-561.

8. Edwards K., Johnstone, C., and Thompson, C. 1991. A simple and rapid method for preparation of plant genomic DNA for the PCR analysis. Nucleic Acids Res. 19:1349.

9. Gardan L., Shafik, H., Belouin, S., Broch, R., and Grimont, F. 1999. DNA relatedness among the pathovars of Pseudomonas syringae and description of Pseudomonas tremae sp. nov. and Pseudomonas cannabina sp. nov. (ex Sutic and Dowson 1959). Int. J. Syst. Bacteriol. 49: 469-478.

10. Hanahan, D. 1983. Studies on transformation of Escherichia coli with plasmids. J. Mol. Biol. 166:557-580.

11. Huang, H.-C., Lin, R.-H., Chang, C.-J., Collmer, A. and Deng, W.-L. 1995. The complete hrp gene cluster of Pseudomonas syringae pv. syringae 61 includes two blocks of genes required for harpin ${ }_{\text {Pss }}$ secretion that are arranged colinearly with Yersinia ysc homologs. Mol. Plant-Microbe Interact. 8:733-746.

12. Kerkoud, M., Manceau, C., Gardan, L., Samson, R., and Paulin, J. P. 2000. Epiphytic occurrence of Pseudomonas syringae pv. papulans (Rose) in France, where blister spot has never been seen. Eur. J. Plant Pathol. 106:481-485.

13. King, E. O., Ward, M. K., and Raney, D. E. 1954. Two simple media for the demonstration of pyocyanin and fluorescein. J. Lab. Clin. Med. 44: 301-307.

14. Leite, R. P., Jones, J. B., Somodi, G. C., Minsavage, G. V., and Stall, R. E. 1995. Detection of Xanthomonas campestris pv. vesicatoria associated with pepper and tomato seed by DNA amplification. Plant Dis. 79:917922.

15. Liang, L. Z., and Jones, A. L. 1995. Organization of the hrp gene cluster and nucleotide sequence of the hrpL gene from Pseudomonas syringae pv. morsprunorum. Phytopathology 85:118-123.

16. Lindgren, P. B., Peet, R. C., and Panapoulos, N. J. 1986 Gene cluster of Pseudomonas syringae pv. phaseolicola controls pathogenicity on bean plants and hypersensitive on non-host plant. J. Bacteriol. 168:515522.

17. Lonetto, M. A., Brown, K. L., Rudd, K. E., and Buttner, M. 1994. Analysis of the Streptomyces coelicolor sigE gene reveals the existence of a sub-family of eubacterial RNA polymerase sigma factors involved in the regulation of extracytoplasmic functions. Proc. Natl. Acad. Sci. USA 91: 7573-7577.

18. Louws, F. J., and Cuppels, D. A. 2001. Molecular techniques. Pages 321333 in: Laboratory Guide for Identification of Plant Pathogenic Bacteria. 3rd ed. N. W. Schaad, J. B. Jones, and W. Chun, eds. The American Phytopathological Society, St. Paul, MN.

19. Maniatis, T., Fritsch, E. F., and Sambrook, J. 1982. Molecular Cloning: A Laboratory Manual. Cold Spring Harbor Laboratory, Cold Spring Harbor, NY.

20. Mansfield, J., Jenner, C., Hockenhull, R., Bennett, M. A., and Stewart, R. 1994. Characterization of $a v r P p h \mathrm{E}$, a gene for cultivar specific avirulence from Pseudomonas syringae pv. phaseolicola which is physically linked to $h r p Y$, a new hrp gene identified in the halo-blight bacterium. Mol. Plant-Microbe Interact. 7:726-739.

21. Moltmann, E. 2000. Die blasenfleckenkrankheit an 'Delbarestivale'verursacht durch Pseudomonas syringae pv. papulans. Obstbau 8:457458.

22. Pooler, M. R., Ritchie, D. F., and Hartung, J. S. 1996. Genetic relationships among strains of Xanthomonas fragariae based on random amplified polymorphic DNA PCR, repetitive extragenic palindromic PCR, and enterobacterial repetitive intergenic consensus PCR data and generation of multiplexed PCR primers useful for the identification of this phytopathogen. Appl. Environ. Microbiol. 62:31213127.

23. Roberts, P. D., Jones, J. B., Chandler, C. K., Stall, R. E., and Berger, R. D. 1996. Survival of Xanthomonas fragariae on strawberry in summer nurseries in Florida detected by specific primers and nested polymerase chain reaction. Plant Dis. 80:1283-1288.

24. Sambrook, J., Fritsch, E. F., and Maniatis, T. 1989. Molecular Cloning: A Laboratory Manual. 2nd ed. Cold Spring Harbor Laboratory, Cold Spring Harbor, NY.

25. Sawada, H., Suzuki, F., Matsuda, I., and Saitou, N. 1999. Phylogenetic 
analysis of Pseudomonas syringae pathovars suggests the horizontal gene transfer of $\arg K$ and evolutionary stability of $h r p$ genes cluster. J. Mol. Evol. 49:627-644.

26. Schaad, N. W., Cheong, S. S., Tamaki, E., Hatziloukas, E., and Panopoulos, N. J. 1995. A combined biological and enzymatic amplification (BIOPCR) technique to detect Pseudomonas syringae pv. phaseolicola in bean seed extracts. Phytopathology 85:243-248.

27. Xiao, Y., Heu, S., Ti, J., Lu, Y., and Hutcheson, S. W. 1994. Identification of a putative alternative sigma factor and characterization of a multicomponent regulatory cascade controlling the expression of Pseudomonas syringae pv. syringae Pss61 hrp and hrmA genes. J. Bacteriol. $174: 1025-1036$ 